\title{
Hypoxia and Glucose Independently Regulate the $\beta$-Adrenergic Receptor-Adenylate Cyclase System in Cardiac Myocytes
}

Krishna J. Rocha-Singh, Norman Y. Honbo, and Joel S. Karliner

Cardiology Section, Department of Veterans Affairs Medical Center and the Cardiovascular Research Institute,

University of California, San Francisco, California 94121

\section{Abstract}

We explored the effects of two components of ischemia, hypoxia and glucose deprivation, on the $\beta$-adrenergic receptor $(\beta A R)$-adenylate cyclase system in a model of hypoxic injury in cultured neonatal rat ventricular myocytes. After 2 h of hypoxia in the presence of $5 \mathrm{mM}$ glucose, cell surface $\beta A R$ density $\left({ }^{3} \mathrm{H}-\mathrm{CGP}-12177\right.$ ) decreased from $54.8 \pm 8.4$ to $39 \pm 6.3$ (SE) fmol/mg protein $(n=10, P<0.025)$, while cytosolic $\beta$ AR density ( ${ }^{125}$ I-iodocyanopindolol [ICYP]) increased by $74 \%$ ( $n$ $=5, P<0.05)$. Upon reexposure to oxygen cell surface $\beta A R$ density returned toward control levels. Cells exposed to hypoxia and reoxygenation without glucose exhibited similar alterations in $\beta A R$ density.

In hypoxic cells incubated with $5 \mathrm{mM}$ glucose, the addition of $1 \mu \mathrm{M}(-)$-norepinephrine (NE) increased cAMP generation from $29.3 \pm 10.6$ to $54.2 \pm 16.1 \mathrm{pmol} / 35 \mathrm{~mm}$ plate $(n=5, P$ $<0.025)$; upon reoxygenation cAMP levels remained elevated above control $(n=5, P<0.05)$. In contrast, NE-stimulated cAMP content in glucose-deprived hypoxic myocytes fell by $31 \%(n=5, P<0.05)$ and did not return to control levels with reoxygenation. $\beta A R$-agonist affinity assessed by (-)-isoproterenol displacement curves was unaltered after $2 \mathrm{~h}$ of hypoxia irrespective of glucose content. Addition of forskolin $(100 \mu \mathrm{M})$ to glucose-supplemented hypoxic cells increased cAMP generation by $60 \%(n=5 ; P<0.05)$, but in the absence of glucose this effect was not seen.

In cells incubated in glucose-containing medium, the decline in intracellular ATP levels was attenuated after $\mathbf{2 ~ h}$ of hypoxia (21 vs. $40 \%, P<0.05)$. Similarly, glucose supplementation prevented $\mathbf{L D H}$ release in hypoxic myocytes.

We conclude that (a) oxygen and glucose independently regulate $\beta A R$ density and agonist-stimulated CAMP accumulation; (b) hypoxia has no effect on $\beta A R$-agonist or antagonist affinity; (c) $5 \mathrm{mM}$ glucose attenuates the rate of decline in cellular ATP levels during both hypoxia and reoxygenation; and (d) glucose prevents hypoxia-induced LDH release, a marker of cell injury. (J. Clin. Invest. 1991. 88:204-213.) Key words: $\beta$-adrenergic receptor $\bullet$ CAMP $•$ hypoxia $\bullet$ glucose

\section{Introduction}

Recent approaches to the treatment of acute ischemia have attempted to favorably alter cardiac metabolism and thereby

\footnotetext{
Address correspondence and reprint requests to Dr. Joel S. Karliner, Cardiology Section (111C), Department of Veterans Affairs Medical Center, 4150 Clement Street, San Francisco, CA 94121.

Received for publication 30 June 1989 and in revised form 1 February 1991.
}

The Journal of Clinical Investigation, Inc.

Volume 88, July 1991, 204-213 improve myocardial cell survival. With the onset of ischemia, morphological, functional, and metabolic changes occur in myocardial cells. After brief periods of reduced blood flow, reperfusion results in a prompt return of cardiac function and metabolism. Longer periods of reduced blood flow may cause myocardial function to be depressed for hours or days ("stunned myocardium") (1). However, with prolonged ischemia, irreversible myocardial cell damage ensues (2). The major determinants of the transition between reversible and irreversible injury include the severity of coronary blood flow reduction, the cellular concentrations of high energy phosphates and substrates, and the rate of metabolic waste removal from the heart (3-7).

Among the factors influencing the extent of cell injury, hypoxia and glucose deprivation are of particular importance. Hearse and Chain reported a correlation between low $\mathrm{pO}_{2}$ during anoxic myocardial perfusion and the fall of myocardial ATP concentration (3). It was suggested that ATP depletion represents a marker of irreversible cell injury and could limit myocardial cell survival. Introduced a quarter century ago by Sodi-Pallares and co-workers, glucose-insulin-potassium (GIK) infusion represented an attempt to arrest myocardial damage during acute infarction (8). Subsequent studies into the beneficial mechanism of GIK indicated that glucose reduced the use of free fatty acids thereby decreasing myocardial oxygen consumption and retarding progressive myocardial injury (9). Nuclear magnetic resonance studies suggest that exogenously supplied glucose may supplement endogenous glycogen mobilization, delay glycogen depletion and prolong the production of high energy phosphates required by myocardial cell metabolism (10).

However, these studies have focused primarily on clinical and metabolic end points as an indirect reflection of myocardial cell survival during ischemia. The independent effects of two important elements of ischemia, hypoxia and glucose deprivation, on the viability of isolated myocytes and their effect on the $\beta$-adrenergic receptor $(\beta A R)^{1}$ adenylate cyclase system are largely unknown. In part this is due to intrinsic difficulties in pursuing these questions in the ischemic heart in vivo. Variables include the influences of sympathetic cardiac stimulation, elevated circulating catecholamine levels, a heterogenous cell population, and the lack of methods for producing a uniform ischemic insult. The results of studies using purified myocardial membranes prepared from in vivo ischemic myocardium to investigate the consequences of acute ischemia or hypoxia on the $\beta$ AR-adenylate cyclase system are inconsistent (11-20). Recent observations in our laboratory suggest that variations in the preparation of purified membranes may, in

1. Abbreviations used in this paper: $\beta \mathrm{AR}, \beta$-adrenergic receptor; IBMX, isobutylmethylxanthine; $\mathrm{LDH}$, lactate dehydrogenase; NE, norepinephrine. 
part, explain these discrepancies (21). Therefore, we used intact cultured neonatal rat ventricular myocytes to assess the independent effects of hypoxia and glucose deprivation on components of the $\beta$-adrenergic receptor-adenylate cyclase system and myocardial cell viability.

\section{Methods}

Ventricular myocardial cell preparation. Primary cell cultures were composed of single isolated ventricular myocytes prepared from hearts of 1-d-old rats as previously described (22). Cells were obtained by brief alternating cycles of room temperature trypsinization and mechanical dissociation. Cells were washed and preplated with $5 \%$ fetal calf serum to reduce the number of contaminating nonmyocardial cells. After 30 min nonattached myocardial cells were removed, counted, and diluted in MEM with HBSS containing 5\% bovine calf serum and plated at a density of $\sim 550$ cells per $\mathrm{mm}^{2}$ into either 100 - or $35-\mathrm{mm}$ Pyrex plates. This medium was supplemented with $1.5 \mu \mathrm{M} \mathrm{B}_{12}$ and $50 \mathrm{U} / \mathrm{ml}$ penicillin was used. The medium through day 3 contained $0.1 \mathrm{mM}$ bromodeoxyuridine to prevent low level nonmyocardial cell proliferation as previously reported (22). Medium was routinely changed on day 4 .

Cell yield was 5-7 million per heart of which $\sim 90 \%$ were viable. All cultures were kept at $37^{\circ} \mathrm{C}$ in humidified air with $1 \% \mathrm{CO}_{2}$ to maintain pH 7.3. The cultures contained $>90 \%$ myocardial cells and cell numbers were constant over time.

Induction of hypoxia. To assess the effect of hypoxia on components of the $\beta$-adrenergic-adenylate cyclase system, $7-\mathrm{ml}$ aliquots of MEM with Earle's BSS were gassed with $95 \% \mathrm{~N}_{2} / 5 \% \mathrm{CO}_{2}$ for $30 \mathrm{~min}$ in an air-tight plexiglass gas perfusion chamber. Gas samples were obtained via an outlet port by suction directly into a Fyrite Gas Analyzer (United Technologies, Pittsburgh, PA). Samples measured before and at the completion of medium gassing verified the absence of ambient chamber $\mathrm{O}_{2}$. All experiments were performed on days 5-7 after plating. The method of exposing the myocytes to hypoxia was as follows: gassed 7-ml aliquots of medium were transferred by pipet to Pyrex culture dishes containing myocytes rinsed with medium to remove residual serum. Plates were then transferred to the gas perfusion chamber for varying time periods at $37^{\circ} \mathrm{C}$. In nine determinations, $2 \mathrm{~h}$ of hypoxia resulted in a medium $\mathrm{pO}_{2}$ of $23.9 \pm 1.5 \mathrm{Torr}, \mathrm{pH}$ of $7.34 \pm 0.02$, and $\mathrm{pCO}_{2}$ of $46.6 \pm 0.7$ Torr as analyzed by a Radiometer ABL30 Acid-Base Blood Gas Analyzer (Copenhagen, Denmark). These levels are similar to those reported by others.

In concurrent experiments, normoxic conditions were created by placing Pyrex culture dishes in a Forma Scientific incubator gassed with $95 \%$ air $/ 5 \% \mathrm{CO}_{2}$ at $37^{\circ} \mathrm{C}$. Plates were first rinsed with warm MEM-Earle's BSS then incubated in this medium for varying time intervals. Analysis of this medium in six separate determinations verified a pH of $7.4 \pm 0.02, \mathrm{pO}_{2}$ of $166.4 \pm 1.3$ Torr and $\mathrm{pCO}_{2}$ of $41.4 \pm 0.6$ Torr. Intact cells were used for analyses of $\beta$-adrenergic receptor density and affinity and intracellular CAMP and ATP content and lactate dehydrogenase release (see below).

To assess the potential effect of glucose deprivation on the $\beta$-adrenergic receptor-adenylate cyclase system, glucose-free MEM-Earle's BSS was substituted for $5 \mathrm{mM}$ glucose-containing MEM-Earle's BSS under both the normoxic and hypoxic experimental conditions described above.

Reoxygenation was accomplished by placing uncovered dishes from the gas perfusion chamber in a Forma Scientific Incubator (Marietta, $\mathrm{OH}$ ) at ambient $\mathrm{pO}_{2}$ for $2 \mathrm{~h}$. At the end of reoxygenation medium $\mathrm{pO}_{2}$ was 110-120 Torr, $\mathrm{pCO}_{2}$ was 32-40 Torr, and $\mathrm{pH}$ was 7.3-7.45.

Radioligand binding studies. For radioligand binding studies cells were incubated for varying time periods under normoxic or hypoxic conditions in the presence or absence of $5 \mathrm{mM}$ D-glucose. Myocardial cells were prepared by rapid washing with $5 \mathrm{ml}$ of the following "CGP buffer": $153 \mathrm{mM} \mathrm{NaCl}, 10 \mathrm{mM}$ Tris, $5 \mathrm{mM} \mathrm{MgCl}_{2}, 0.65 \mathrm{mU}$ aprotinin, adjusted to $\mathrm{pH}$ 7.4. Cells were immediately harvested using a rubber spatula and suspended in CGP buffer; cell aggregation was minimized by two to three strokes in a glass homogenizing tube and filtration through a single layer of 110 mesh nylon gauze (Nitex; Tetkco, Inc., Los Angeles, CA). Preliminary experiments documented $>80 \%$ trypan blue exclusion using this method.

The cell suspension was incubated with $( \pm)-\left[{ }^{3} \mathrm{H}\right] 4-(3-t-b u t y l a m i-$ no-2-hydroxypropoxy)benzimidazol-2-one hydrochloride $\left({ }^{3} \mathrm{H}-\mathrm{CGP}\right.$ $12177)(0.01-20 \mathrm{nM})$ in a total volume of $0.5 \mathrm{ml}$ in $12 \times 75-\mathrm{mm}$ polypropylene tubes. Detailed analysis of the binding characteristics of this compound has previously been reported (23). Preliminary experiments in our cells revealed that binding equilibrium was reached after $45 \mathrm{~min}$ of incubation at $37^{\circ} \mathrm{C}$. Nonspecific binding was assessed using 1 $\mu \mathrm{M}(-)$-propranolol. The binding reaction was terminated by adding 4 $\mathrm{ml}$ of ice-cold $40 \mathrm{mM} \mathrm{KPO} / 4 \mathrm{mM} \mathrm{MgSO} 4$ buffer followed by immediate filtration through glass fiber filters (Whatman GF/C; Clifton, NJ) using a Brandel Cell Harvester (Brandel Laboratories, Gaithersburg, MD). This procedure was followed by four additional washes of $4 \mathrm{ml}$ each. Retained radioactivity was counted $24 \mathrm{~h}$ after the addition of $7 \mathrm{ml}$ of scintillation fluid (Cytoscint; Amersham Corp., Arlington Heights, IL) in a scintillation counter (LS 350; Beckman Instruments, Inc., Fullerton, CA) at a counting efficiency of $38 \%$. Specific binding was defined as the difference between total binding and nonspecific binding and ranged from $65-80 \%$. All determinations were performed in duplicate. The maximum number of binding sites $\left(B_{\max }\right)$ and the equilibrium $\mathrm{Kd}$ were determined by least squares linear regression analysis using the method of Scatchard (24).

To measure membrane and cytosolic $\beta$-adrenergic receptor populations from the same cells under normoxic and hypoxic conditions, intact myocytes were washed three times with $1 \mathrm{mM}$ Tris/2 mM EGTA and lysed in situ in this hypotonic buffer for $20 \mathrm{~min}$ at $4^{\circ} \mathrm{C}$ as previously described (25). The resultant particulate preparation was harvested using a rubber spatula and placed in $18 \times 100$-mm polycarbonate tubes and centrifuged at $40,000 \mathrm{~g}$ for $30 \mathrm{~min}$. The pellet was resuspended in $50 \mathrm{mM}$ Tris $\mathrm{HCl} / 1 \mathrm{mM} \mathrm{MgCl}, \mathrm{pH} 7.4$, and stored at $-70^{\circ} \mathrm{C}$; the supernatant of the original $40,000 \mathrm{~g}$ centrifugation was transferred to $16 \times 102-\mathrm{mm}$ polyallomer tubes (Beckman) and centrifuged at $125,000 \mathrm{~g}$ for $24 \mathrm{~h}$ at $4^{\circ} \mathrm{C}$ in a Beckman $\mathrm{L} 350$ ultracentrifuge. For assay, $80 \mu \mathrm{l}$ of each cell fraction preparation was incubated with 10 $\mu 1$ of $( \pm)^{125}$ I-iodocyanopindolol (ICYP), which has binding characteristics similar to (-)- $-125 \mathrm{I}-\mathrm{ICYP}(26)$, at a final concentration ranging from 20 to $200 \mathrm{pM}$, in a total volume of $100 \mu \mathrm{l}$ at $37^{\circ} \mathrm{C}$, in $12 \times 75-\mathrm{mm}$ polypropylene tubes for $30 \mathrm{~min}$., at which time the plateau of the binding reaction was reached. Nonspecific binding was assessed by the addition of $1 \mu \mathrm{M}(-)$-propranolol (final concentration). Binding reactions were terminated by the addition of $10-15 \mathrm{ml}$ of $50 \mathrm{mM}$ Tris $\mathrm{HCl} / 10$ $\mathrm{mM} \mathrm{MgCl} 2$ and the contents immediately filtered through glass fiber filters (Whatman GF/C) and counted in a gamma counter (Beckman 5800 ) at an efficiency of $73 \%$. All determinations were carried out in triplicate (membrane fractions) or duplicate (cytosolic fractions). Protein content was determined by the method of Lowry et al. (27). For membranes, each assay tube contained 13-15 $\mu \mathrm{g}$ protein and for cytosolic determinations, each tube contained 5-8 $\mu \mathrm{g}$ protein.

For (-)-isoproterenol displacement curves a particulate fraction from normoxic and hypoxic cells was prepared as described above. 10 $\mu l$ of ${ }^{125} \mathrm{I}-\mathrm{ICYP}\left(20 \mathrm{pM}\right.$ final concentration) were incubated at $37^{\circ} \mathrm{C}$ for $30 \mathrm{~min}$ in the presence of varying concentrations of $(-)$-isoproterenol $(10 \mathrm{nM}$ to $100 \mu \mathrm{M})$ after the reaction was initiated by the addition of 80 $\mu \mathrm{l}$ of the membrane preparation. Displacement experiments were performed in the presence and absence of $100 \mu \mathrm{M} \mathrm{GTP}$. The binding assay was performed as described above. Previous studies in our laboratory and by others $(25,28,29)$ using these techniques have indicated that neonatal rat ventricular myocytes, like adult rat myocytes (30), contain predominantly $\beta_{1}$-adrenergic receptors.

cAMP Radioimmunoassay. The effect of hypoxia in the presence and absence of $5 \mathrm{mM}$ D-glucose on (-)-norepinephrine-stimulated intracellular cAMP generation was determined according to a modification of a previously described method (31). Briefly, myocardial cells were plated in 35-mm Pyrex dishes and subjected to normoxic or hypoxic conditions as described above. $5 \mathrm{~min}$ before the addition of varying concentrations of (-)-norepinephrine, 3-isobutyl-1-methylxathine 
(IBMX) was added to the medium to achieve a final concentration of 1 $\mathrm{mM}$. After $5 \mathrm{~min}$ of incubation with (-)-norepinephrine, cells were eluted with $3 \mathrm{ml}$ of $95 \%$ ethanol, and the eluent transferred to $12 \times 75$ $\mathrm{mm}$ borosilicate glass tubes, air dried, and stored at $4^{\circ} \mathrm{C}$ for up to $1 \mathrm{mo}$, which did not affect the results. At the time of assay the pellet was thawed and resuspended in $300 \mu \mathrm{l} 0.05 \mathrm{M} \mathrm{NaOAc}, \mathrm{pH} 6.2 ; 100 \mu \mathrm{l}$ of this resuspension or $100 \mu \mathrm{l}$ of cAMP standard was added to $100 \mu \mathrm{l}$ of ${ }^{125}$ I-succinyl-cAMP tyrosine methyl ester tracer (6-12,000 cpm). $100 \mu 1$ of goat cAMP antibody in sodium acetate buffer containing $2 \mathrm{mg} / \mathrm{ml}$ bovine gamma globulin was then added in a final dilution of $1: 240,000$ and incubated overnight on ice; $1.5-\mathrm{ml}$ polyethylene glycol-gamma globulin solution ( $160 \mathrm{mg}$ polyethylene glycol per $\mathrm{ml}$ of $0.1 \%$ bovine gamma globulin solution) was added to each tube and the precipitated antibody-antigen complex centrifuged at 40,000 rpm (Sorvall TB3500; DuPont Co., Wilmington, DE) for $\mathbf{4 0} \mathrm{min}$. After aspiration of residual supernatant from this spin, the ${ }^{125} \mathrm{I}$-antigen-antibody complex was counted for $1 \mathrm{~min}$ in a gamma counter (Beckman 5800) at an efficiency of $73 \%$. The results from two plates per condition, each analyzed in duplicate, were averaged for each data point and reported as pmol cAMP/35 mm plate, each of which contained $100-130,000$ cells or 65-75 $\mu \mathrm{g}$ protein.

Adenosine triphosphate assay. To assess the effect of hypoxia on intracellular ATP content in the presence and absence of $5 \mathrm{mM} \mathrm{D-glu-}$ cose, a fluorometric assay was used as described by Lowry and Passenau (32). Myocytes were harvested by removing medium and $400 \mu \mathrm{I}$ of $1 \mathrm{M}$ perchloric acid was added immediately. A 350- $\mu$ l aliquot was transferred to a microcentrifuge tube; the extract was neutralized with 3 $\mathrm{M} \mathrm{KOH} / 50 \mathrm{mM}$ imidazole and stored at $-70^{\circ} \mathrm{C}$. On the day of assay, the sample was thawed, vortexed, and centrifuged to pellet the $\mathrm{KClO}_{4}$. $100 \mu \mathrm{l}$ of supernatant was added to $900 \mu \mathrm{l}$ of ATP reagent ( $50 \mathrm{mM}$ Tris $\mathrm{HCl}, \mathrm{pH}$ 8.1/1 $\mathrm{mM} \mathrm{MgCl} / 0.2 \mathrm{mM}$ glucose/0.02\% BSA/0.1 mM nicotinamide adenine dinucleotide phosphate $/ 70 \mathrm{mU} / \mathrm{ml}$ glucose-6-phosphate dehydrogenase). The samples and the ATP standard curve were read at $340 \mathrm{~nm}$ before and after the addition of $10 \mu \mathrm{l}$ hexokinase (140 $\mathrm{U} / \mathrm{mg}$ ). ATP content was expressed as nmol per $\mathrm{mg}$ protein.

Lactate dehydrogenase assay. The effect of hypoxia in the presence and absence of $5 \mathrm{mM}$ D-glucose on cellular lactate dehydrogenase (LDH) release was assessed as follows: 5-7-d-old myocytes plated on $100 \mathrm{~mm}$ Pyrex dishes were washed with warm MEM-Earle's BSS to remove residual serum and then exposed to varying durations of hypoxia in $3 \mathrm{ml}$ of MEM-Earle's BSS in the presence and absence of $5 \mathrm{mM}$ D-glucose. At the end of the hypoxic period, medium was removed, vortexed, and stored briefly on ice. A $100-\mu$ l aliquot was assayed for LDH activity using a Kodak Ektachem Multi-Channel Analyzer. Arbitrary 0 and $100 \% \mathrm{LDH}$ release values were determined by assaying medium LDH after each designated time point under normoxic conditions and after a single $-70^{\circ} \mathrm{C}$ freeze-thaw cycle. LDH was then expressed as a percentage of maximum LDH release.

Data analysis. Results are expressed as mean $\pm \mathrm{SE}$ and were compared using Student's $t$ test for paired data; a $P$ value of $<0.05$ was considered significant.

Materials. ${ }^{3} \mathrm{H}$-CGP-12177 $(30-35 \mathrm{mCi} / \mathrm{mmol})$ was from Amersham Corp. and ${ }^{125} \mathrm{I}-\mathrm{ICYP}(2,200 \mathrm{mCi} / \mathrm{mmol})$ was from New England Nuclear (Boston, MA). Hexokinase and glucose-6-phosphate dehydrogenase were from Boehringer-Mannheim Corp. (Indianapolis, IN) (-)propranolol was a generous gift from Ayerst Laboratories, Inc., (New York). The goat cAMP antibody used for the cAMP-RIA was a gift from Dr. Hunter Heath, Rochester, MN. All other reagents were from Sigma Chemical Co., St. Louis, MO.

\section{Results}

The influence of hypoxia alone on cell surface $\beta$-adrenergic receptor density. We first investigated the effect of hypoxia in the presence of glucose on cell surface $\beta$-adrenergic receptor density in intact ventricular myocytes using the hydrophilic radioligand ${ }^{3} \mathrm{H}-\mathrm{CGP}-12177$. After $1 \mathrm{~h}$ of hypoxia cell surface $\beta$-re- ceptor density fell by $20 \%$ from $58.6 \pm 7.9$ to $47.1 \pm 6.1 \mathrm{fmol} / \mathrm{mg}$ protein $(n=4, P<0.02)$; antagonist $K_{\mathrm{d}}$ was unchanged from control. After $2 \mathrm{~h}$ of hypoxia $\beta$-adrenergic receptor density fell by $27.4 \%$ from $54.8 \pm 8.4$ to $39.8 \pm 6.25 \mathrm{fmol} / \mathrm{mg}$ protein, an additional $8 \%$ decline from $1 \mathrm{~h}$ of hypoxia $(n=10 ; P<0.025)$ (Fig. 1). Antagonist $K_{\mathrm{d}}$ was not significantly altered (2.6 \pm 0.84 vs. $2.05 \pm 0.65 \mathrm{nM}, n=10$ ).

We then determined the effect of reoxygenation on cell surface $\beta$-adrenergic receptor density. In a separate series of experiments two groups of myocytes were exposed to $2 \mathrm{~h}$ of hypoxia; one group was assayed for $\beta$-adrenergic receptor density with ${ }^{3} \mathrm{H}-\mathrm{CGP}-12177$ at the end of the hypoxic exposure as described
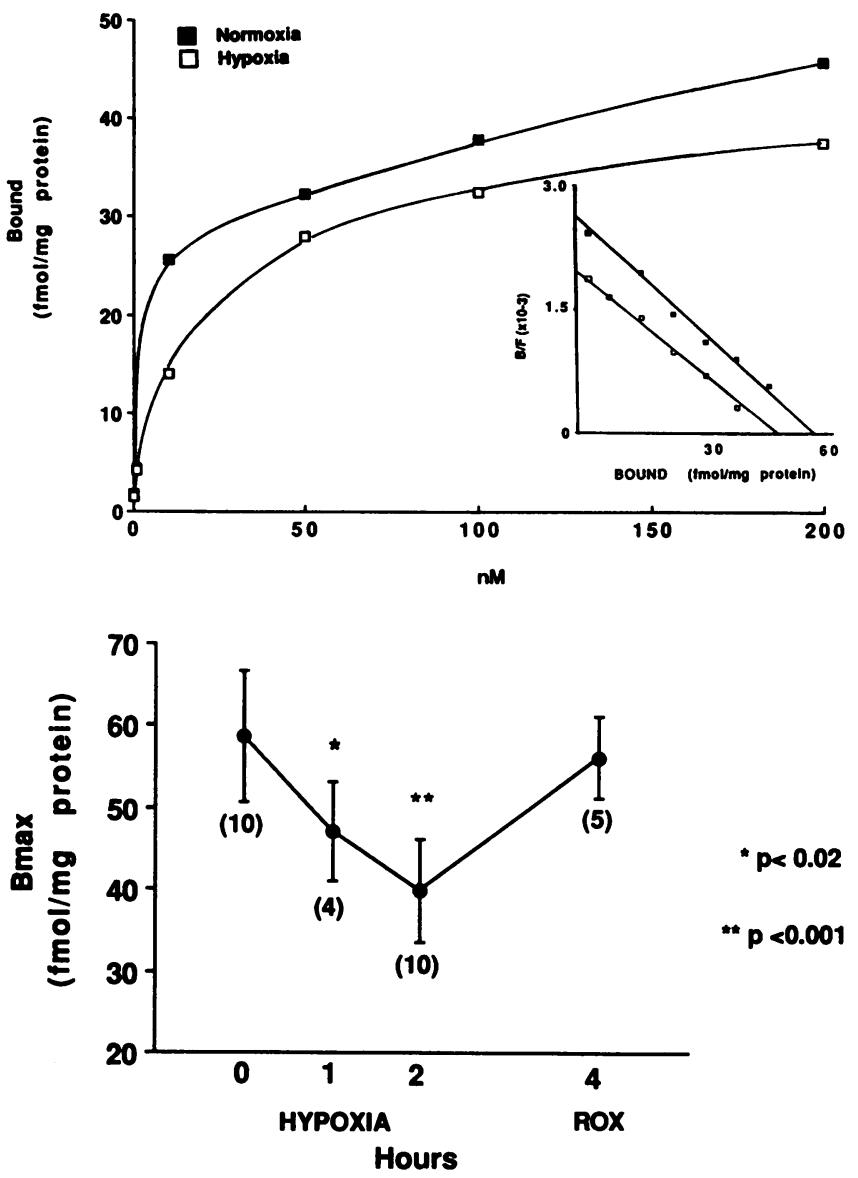

Figure 1. Hypoxia-induced $\beta$-adrenergic receptor downregulation and the effect of reoxygenation. Cell surface $\beta$-adrenergic receptors were measured using the hydrophilic radioligand ${ }^{3} \mathrm{H}-\mathrm{CGP}-12177$ in intact neonatal rat ventricular myocytes. Myocytes were exposed to hypoxic medium in the presence of glucose. After 60 and $120 \mathrm{~min}$ of hypoxia $\beta$-adrenergic receptor density was significantly reduced as compared with control values. Similar results were obtained after $120 \mathrm{~min}$ of hypoxia in the absence of $5 \mathrm{mM}$ D-glucose $(n=3, P<0.05)$. In a series of separate experiments, after $2 \mathrm{~h}$ of hypoxia, myocytes were reoxygenated either in the presence or absence of glucose in room air for $120 \mathrm{~min}$; each condition was associated with a return of $\beta$-adrenergic receptor density to control values (see text for details). (Top) Representative equilibrium binding experiments. Closed squares, normoxia; open squares, hypoxia. Data shown are specific binding curves. Inset shows Scatchard transformation of these data. (Bottom) Data summary. Each point is the mean \pm SE. Numbers in parentheses refer to the number of determinations at each time point. $B_{\max }$, $\max$ imum number of binding sites; $R O X$, reoxygenation. 
above, while the other was reoxygenated in ambient $\mathrm{O}_{2}$ for $2 \mathrm{~h}$ and then assayed. Analysis of medium $\mathrm{pO}_{2}$ analysis documented a return toward normoxic control values (118 \pm 12 Torr). As depicted in Fig. 1, hypoxia caused a loss of cell surface $\beta$-adrenergic receptors while reoxygenation was associated with a return of receptor density to control levels $(56.2 \pm 4.4$ vs. $56.1 \pm 4.9 \mathrm{fmol} / \mathrm{mg}$ protein; $n=5, P=\mathrm{NS}$ ).

The influence of hypoxia combined with glucose deprivation on cell surface $\beta$-adrenergic receptor density. To elucidate the possible consequences of glucose deprivation on hypoxia-induced $\beta$-adrenergic receptor downregulation, we performed experiments after $2 \mathrm{~h}$ of hypoxia using glucose-free medium. Hypoxia in the absence of glucose was associated with a $29 \%$ loss of $\beta$-adrenergic receptors from $55.6 \pm 7.8$ to $39.0 \pm 2.3 \mathrm{fmol} / \mathrm{mg}$ protein $(P=0.01, n=3)$, a reduction identical to hypoxia-induced downregulation in the presence of glucose. Similarly, antagonist $K_{d}$ was not affected by the presence or absence of glucose under either normoxic or hypoxic conditions. Furthermore, the absence of glucose had no impact on the reoxygenation-associated return of $\beta$-adrenergic receptor density to control levels after hypoxia $(55.6 \pm 7.8$ vs. $55.0 \pm 2.6 \mathrm{fmol} / \mathrm{mg}$ protein, $n=3$ ).

Effect of myocardial membrane preparation on $\beta$-adrenergic receptor density. Methods of sarcolemmal purification from myocyte homogenates vary and may influence $\beta$-adrenergic receptor measurements. Numerous investigators have employed preparations in which the initial pellet from the myocyte homogenate spun at a low speed was discarded, eliminating an unknown population of $\beta$-adrenergic receptors (11-20). To determine the potential impact of the method of membrane preparation on $\beta$-adrenergic receptor density in our neonatal rat ventricular myocyte model, we prepared myocyte homogenates in the manner described by Thandroyen et al. (16). After scraping, cells were centrifuged at $1,000 \mathrm{~g}$ for $5 \mathrm{~min}$; the resulting pellet was homogenized in a Dounce apparatus and used in binding studies. The supernatant from this preparation has been routinely discarded by others. We subjected this supernatant fraction to a $125,000 \mathrm{~g}$ ultracentrifugation for $24 \mathrm{~h}$ and performed ${ }^{125} \mathrm{I}$-ICYP binding studies on the resulting pellet. We observed that the $\beta$-adrenergic receptor density in this fraction approximated the concentration in the initial pellet $(68 \pm 18$ vs. $53 \pm 12 \mathrm{fmol} / \mathrm{mg}$ protein, $n=4$ ) (Table I).

In a parallel series of binding studies myocytes were incubated in a hypotonic lysing buffer consisting of $1 \mathrm{mM}$ Tris/2 mM EDTA for $20 \mathrm{~min}$, then scraped and centrifuged at 40,000 $g$ for $30 \mathrm{~min}$. The pellet was assayed for $\beta$-adrenergic receptors; the supernatant was again ultracentrifuged at $125,000 \mathrm{~g}$ for 24 $h$ and the pellet assayed. We observed that this fraction contained less than $10 \%$ of the $\beta$-adrenergic receptors present in the initial pellet $(250 \pm 29$ vs. $23 \pm 4 \mathrm{fmol} / \mathrm{mg}$ protein, $n=5$ ). Based on these results, which indicate that the method of membrane preparation significantly alters the results of $\beta$-adrenergic receptor determinations, we used the hypotonic lysis method of preparing membrane and cytosolic fractions.

Hypoxia causes translocation of $\beta$-adrenergic receptors to a cytosolic fraction. To determine if the decline of cell surface $\beta$-adrenergic receptor density was attributable to receptor downregulation or degradation, we prepared membrane and cytosolic fractions as described above from myocytes exposed to $\mathbf{2} \mathrm{h}$ of hypoxia in the absence of glucose. Previous studies in this laboratory have documented that the pellet from $100,000 \mathrm{~g}$ ultracentrifugation (cytosolic fraction) is enriched in $\beta$-adren-
Table I. Effect of Cardiac Myocyte Sarcolemmal Membrane Preparation Methods on $\beta$-Adrenergic Receptor Density during Normoxia and after 120 min of Hypoxia

\begin{tabular}{lccc}
\hline & & $B_{\max }$ & $K_{\mathrm{d}}$ \\
\hline & $n$ & $f m o l / m g$ protein & $p M$ \\
Method 1 & & & \\
$\quad 1,000 \mathrm{~g}$ pellet & 4 & $68 \pm 18$ & $1.23 \pm 0.4$ \\
$\quad$ Supernatant & & & \\
$\quad 125,000 \mathrm{~g}$ & 4 & $53 \pm 12$ & $1.05 \pm 0.2$ \\
$\begin{array}{l}\text { Method 2 } \\
\text { NORMOXIA }\end{array}$ & & & \\
$\quad 40,000 \mathrm{~g}$ pellet & 5 & $250 \pm 29$ & $1.61 \pm 0.3$ \\
$\quad$ Supernatant & 5 & $23 \pm 4$ & $0.76 \pm 0.1$ \\
$\quad$ HYPOXIA & & & \\
$\quad 40,000 \mathrm{~g}$ pellet & 5 & $200 \pm 23$ & $1.60 \pm 0.3$ \\
$\quad$ Supernatant & 5 & $40 \pm 5$ & $0.85 \pm 0.1$ \\
\hline
\end{tabular}

The effect of cardiac membrane preparation on $\beta$-adrenergic receptor density during normoxia and after $120 \mathrm{~min}$ of hypoxia was evaluated by comparing two previously reported methodologies using neonatal rat ventricular myocytes (see text). Method 1: Cultured myocytes were scraped and centrifuged at $1,000 \mathrm{~g}$ for $5 \mathrm{~min}$ and the pellet was homogenized and analyzed by ${ }^{125}$ I-ICYP binding studies. The supernatant was centrifuged at $125,000 \mathrm{~g}$ for $24 \mathrm{~h}$ and radioligand binding studies were performed. Beta-adrenergic receptor density and $K_{\mathrm{d}}$ (pM) values were not significantly different $(n=4)$. Method 2: Myocytes were lysed in a hypotonic buffer, scraped and centrifuged at $40,000 \mathrm{~g}$ for $30 \mathrm{~min}$, and ${ }^{125} \mathrm{I}$-ICYP binding studies were performed. The supernatant was centrifuged at $125,000 \mathrm{~g}$ for $24 \mathrm{~h}$ and the pellet analyzed. Under normoxic conditions this fraction contained approximately $10 \%$ of the $\beta$-adrenergic receptor density present in the $40,000 \mathrm{~g}$ preparation. The effect of $120 \mathrm{~min}$ of hypoxia on $\beta$-adrenergic receptor density in these two preparations was also assessed. 120 min of hypoxia downregulated membrane-associated $\beta$-adrenergic receptor density by $20 \%$. This decline was accompanied by a $46 \%$ increase in cytosolic $\beta$-adrenergic receptor density. The membrane and cytosolic fraction $\beta$-adrenergic receptor antagonist $K_{\mathrm{d}}$ values under normoxic and hypoxic conditions were unchanged, but differed significantly when compared with each other within the same condition $(P<0.02$ for normoxia, $P<0.05$ for hypoxia). $n$, number of separate experiments; $B_{\max }$, maximum number of binding sites.

ergic receptors after $4 \mathrm{~h}$ of (-)-isoproterenol-induced downregulation but lacks adenylate cyclase activity (25). To confirm the purity of our sarcolemmal preparation, we measured $\mathrm{Na}^{+}$/ $\mathrm{K}^{+}$-ATPase activity (33). Under normoxic conditions, $\mathrm{Na}^{+}$/ $\mathrm{K}^{+}$-ATPase activity in the membrane preparation was $48.7 \pm 3.9 \mu \mathrm{mol} / \mathrm{h}$ and after $2 \mathrm{~h}$ of hypoxia the value was $40 \pm 9.5$ $\mu \mathrm{mol} / \mathrm{h}(n=7, P=\mathrm{NS}$, Fig. 2$)$. In the cytosolic fraction $\mathrm{Na}^{+} /$ $\mathrm{K}^{+}$-ATPase activity was barely detectable in either normoxic or hypoxic preparations $(0.55 \pm 0.37$ vs. $0.51 \pm 0.33 \mu \mathrm{mol} / \mathrm{h} ; n=7$, $P=$ NS, Fig. 2).

After $2 \mathrm{~h}$ of hypoxia $\beta$-adrenergic receptor density in the membrane fraction assessed by ${ }^{125} \mathrm{I}-\mathrm{ICYP}$ binding fell $20 \%$ from $250 \pm 29$ to $200 \pm 23 \mathrm{fmol} / \mathrm{mg}$ protein $(n=5, P<0.05)$ (Table I), while antagonist $K_{\mathrm{d}}$ was unchanged from control values $(1.60 \pm 0.3$ vs. $1.61 \pm 0.29 \mathrm{pM})$. This decrease in membrane receptor density is consistent with the results described above in intact myocytes. After $2 \mathrm{~h}$ of hypoxia $\beta$-adrenergic receptor density in the cytosolic fraction prepared from the supernatant of the membrane fraction increased by $74 \%$ from $23 \pm 4$ to $40 \pm 5 \mathrm{fmol} / \mathrm{mg}$ protein $(n=5, P<0.05)$; antagonist $K_{\mathrm{d}}$ 
TOTAL ATPase ACTIVITY

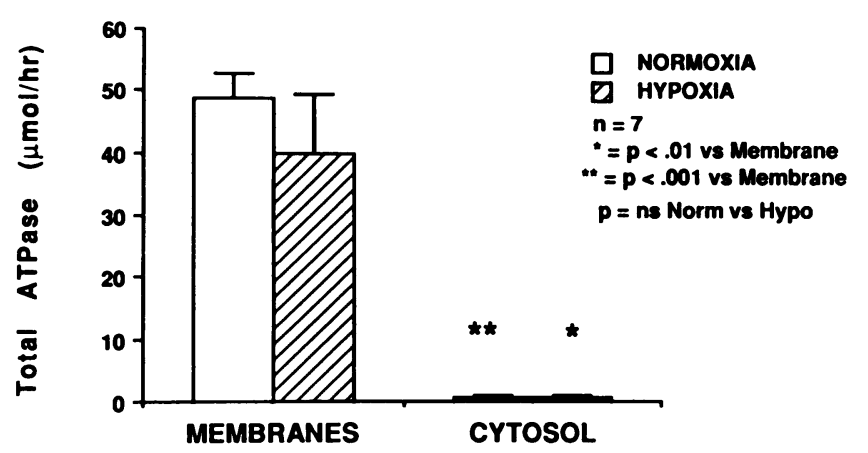

Figure 2. Total $\mathrm{Na}^{+} / \mathrm{K}^{+}$-ATPase activity in membrane and cytosolic preparations from normoxic and hypoxic myocytes. As can be seen, enzyme activity was barely detectable in either normoxic or hypoxic cytosolic preparations. Norm, normoxia; Hypo, hypoxia.

was unchanged $(0.76 \pm 0.1$ vs. $0.85 \pm 0.1 \mathrm{pM})$. Radioligand binding assays performed on the supernatant of the $125,000 \mathrm{~g}$ preparation revealed no evidence of an additional receptor population. These results indicate that the $\beta$-adrenergic receptors detected in the membrane and cytosolic fractions represent the entire cellular $\beta$-adrenergic receptor population. Thus, hypoxia induces downregulation of cell surface $\beta$-adrenergic receptors by translocation to a cytosolic fraction.

The influence of hypoxia and glucose deprivation on (-)-norepinephrine-stimulated cAMP generation. We next asked whether hypoxia in the presence and absence of glucose would alter catecholamine-stimulated cAMP generation. We chose the naturally occurring neurotransmitter, (-)-norepinephrine (NE) for these studies. Preliminary studies revealed that incubation with $1 \mu \mathrm{M}$ NE for 5 min maximally stimulated intracellular cAMP in the presence of $1 \mathrm{mM}$ IBMX. The peak response to NE also occurred at $5 \mathrm{~min}$ in hypoxic cells either in the presence or absence of glucose. Therefore, intact myocytes were first exposed to glucose-free hypoxic medium for $2 \mathrm{~h}$ before stimulation with $1 \mu \mathrm{M}$ NE for $5 \mathrm{~min}$. Under these conditions NE-stimulated intracellular cAMP fell by $31 \%$ from $35.4 \pm 3.8$ to $24.6 \pm 4.1 \mathrm{pmol} / 35-\mathrm{mm}$ plate $(P=0.01, n=5)$. Despite $2 \mathrm{~h}$ of reoxygenation NE-stimulated cAMP levels remained depressed at $23.6 \pm 1.9 \mathrm{pmol} / 35-\mathrm{mm}$ plate. However, addition of $5 \mathrm{mM}$ D-glucose at the onset of reoxygenation returned NE-stimulated cAMP levels to control values (33.4 \pm 4.8 vs. $30.5 \pm 2.7 \mathrm{pmol} / 35-\mathrm{mm}$ plate; $n=5, P=\mathrm{NS}$, Fig. 3 ).

The presence of $5 \mathrm{mM}$ D-glucose during hypoxia and reoxygenation had profound effects on NE-stimulated cAMP generation. After $2 \mathrm{~h}$ of hypoxia in glucose-supplemented medium, NE-stimulated cAMP content rose by $185 \%$ above control levels from $29.3 \pm 10.6$ to $54.2 \pm 16.1 \mathrm{pmol} / 35-\mathrm{mm}$ plate $(P<0.05$, $n=5$ ). After $2 \mathrm{~h}$ of reoxygenation in the presence of glucose, NE-stimulated cAMP levels remained above control at $44.8 \pm 12.3 \mathrm{pmol} / 35-\mathrm{mm}$ plate $(n=5, P<0.05$, Fig. 3 ).

Because of the profound influence of glucose on (-)-norepinephrine-stimulated cAMP content during hypoxia, we explored the possibility that this effect was mediated by enhanced $\beta$-adrenergic receptor-agonist affinity. In membranes prepared from myocytes exposed to hypoxia in the presence and absence of glucose, (-)-isoproterenol displacement curves revealed no alteration in $\beta$-adrenergic receptor-agonist affinity during hypoxia; furthermore, the presence or absence of glucose had no
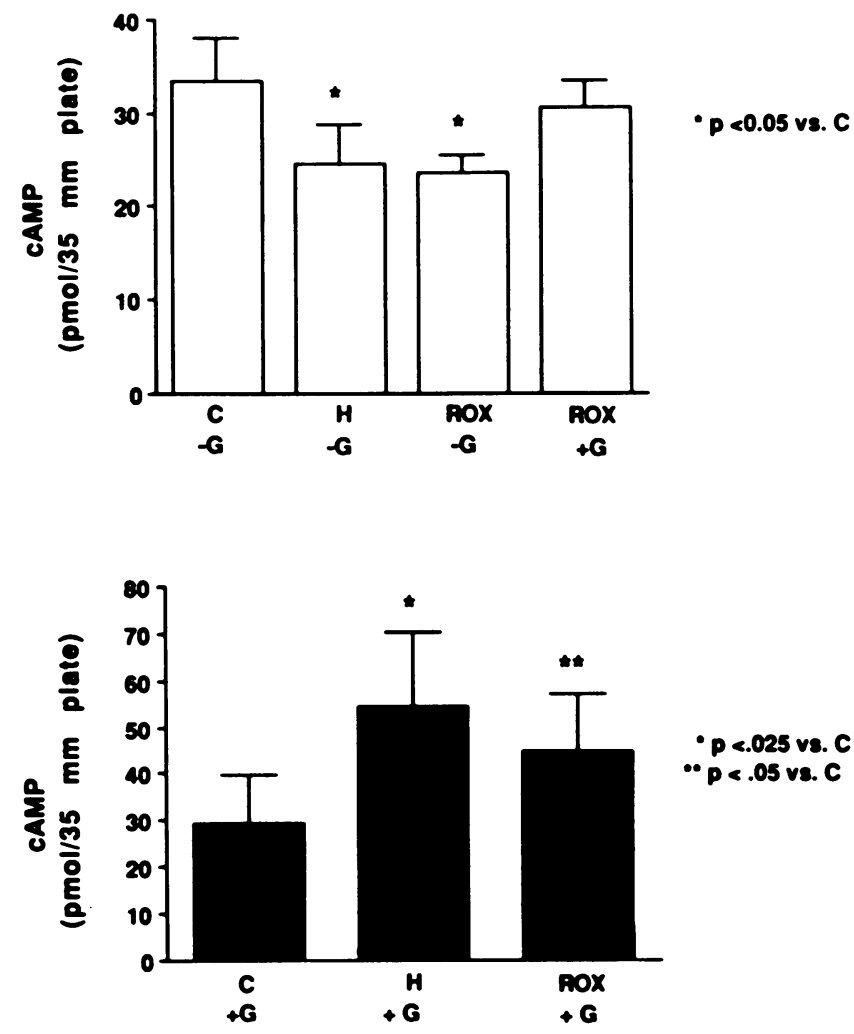

Figure 3. (-)-NE-stimulated cAMP generation during hypoxia and reoxygenation in the presence and absence $5 \mathrm{mM}$ glucose. (Top) Intact myocytes were exposed to $1 \mu \mathrm{M}$ NE for $5 \mathrm{~min}$ after a 5 -min preincubation with $1 \mathrm{mM} \mathrm{IBMX}$ after $120 \mathrm{~min}$ of normoxia $(C), 120$ min of hypoxia $(H)$, and $120 \mathrm{~min}$ of reoxygenation in room air $(R O X)$ in the absence of $5 \mathrm{mM}$ D-glucose $(-G)$ at $37^{\circ} \mathrm{C}$. In the same series of experiments, medium containing $5 \mathrm{mM}$ D-glucose $(G)$ was added at the onset of reoxygenation $(R O X+G)$. Each bar represents the mean \pm SE of five separate determinations. (Bottom) NE-stimulated cAMP generation during hypoxia and reoxygenation in the presence $5 \mathrm{mM}$ D-glucose $(+G)$. Intact myocytes were exposed to 1 $\mu \mathrm{M}$ NE for $5 \mathrm{~min}$ after a 5 -min preincubation with $1 \mathrm{mM}$ IBMX after $120 \mathrm{~min}$ of normoxia $(C), 120 \mathrm{~min}$ of hypoxia $(H)$ in the presence of $5 \mathrm{mM}$ D-glucose at $37^{\circ} \mathrm{C}$. Myocytes were then exposed to room air for $120 \mathrm{~min}$ at $37^{\circ} \mathrm{C}$ in the continued presence of $5 \mathrm{mM} \mathrm{D}$ glucose $(R O X+G)$. Each point is the mean $\pm \mathrm{SE}$ of five separate determinations.

effect on agonist affinity (Fig. 4). GTP $(100 \mu \mathrm{M})$ produced the expected rightward shift in the competition curve.

Effects of hypoxia and glucose deprivation on forskolinstimulated cAMP generation. To determine if substrate depletion could be implicated in the observed decrease in NE-stimulated cAMP generation during hypoxia in the absence of glucose, we used forskolin, an agent which stimulates CAMP accumulation by direct interaction with the catalytic unit of adenylate cyclase and likely, in part, by interaction with the stimulatory guanine nucleotide regulatory protein $\left(\mathrm{G}_{\mathrm{s}}\right)(34$, 35). Because maximal depression of intracellular ATP and NEstimulated cAMP generation was observed after $2 \mathrm{~h}$ of hypoxia in the absence of glucose, experiments with forskolin were performed at this time point. As shown in the left panel of Fig. 5, after $2 \mathrm{~h}$ of hypoxia in the absence of glucose, $100 \mu \mathrm{M}$ forskolin-stimulated cAMP generation did not differ significantly from normoxic conditions. By contrast, after $2 \mathrm{~h}$ of hypoxia in 


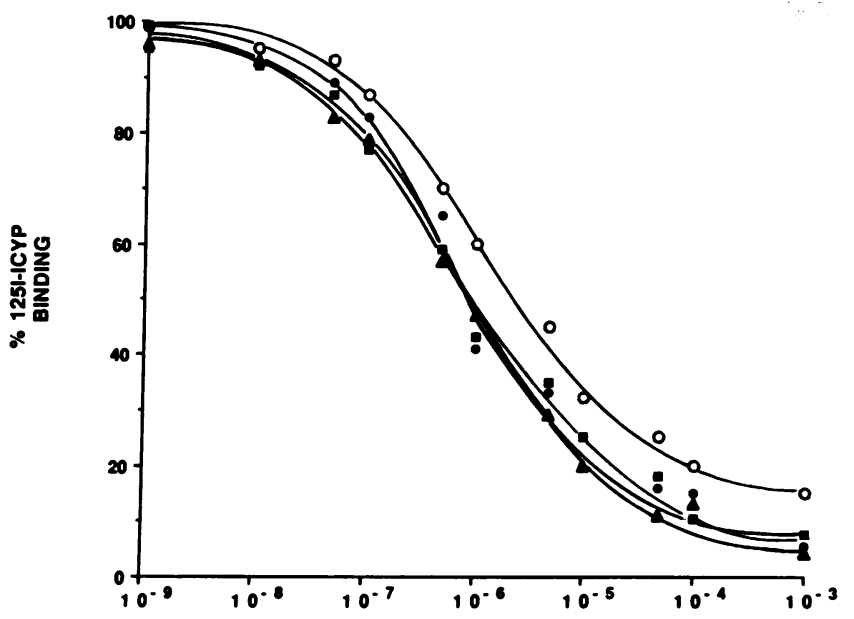

[(-) ISOPROTERENOL] (M)

Figure 4. Competition curves with a range of (-)-isoproterenol concentrations ( $1 \mathrm{nM}-10 \mathrm{mM}$ ) coincubated with $20 \mathrm{pM}{ }^{125} \mathrm{I}-\mathrm{ICYP}$ and membranes prepared from myocytes after $120 \mathrm{~min}$ of exposure to normoxia (triangles), hypoxia in the presence of glucose (squares), and to hypoxia in the absence of glucose (closed circles). There was no effect of hypoxia on agonist- $\beta$-adrenergic receptor affinity. GTP $(100 \mu \mathrm{M})$ produced the expected rightward shift in the competition curve (open circles). Data represent the mean of three experiments, each performed in triplicate. IC50 values $(\mu \mathrm{M})$ were: control, $0.36 \pm 0.1$; hypoxia + glucose, $0.32 \pm 0.2$; hypoxia-glucose, $0.41 \pm 0.2$; and GTP, $0.95 \pm 0.3(P<0.01$ vs. control).

the presence of glucose, forskolin-stimulated cAMP generation was increased over normoxic conditions (Fig. 5, right).

The effect of hypoxia and glucose deprivation on intracellular adenosine triphosphate content. Because of the independent influence of hypoxia and glucose on (-)-norepinephrine-stimulated cAMP content, we asked if high energy phosphate content was similarly altered. As shown in Fig. 6, after $2 \mathrm{~h}$ of exposure to glucose-free hypoxic medium, intracellular ATP levels fell by $40 \%$ from $36.1 \pm 2.8$ to $21.6 \pm 2.5 \mathrm{nmol} / \mathrm{mg}$ protein ( $n=7, P=0.02)$. Despite reoxygenation ATP continued to decline to $10.8 \pm 2.8 \mathrm{nmol} / \mathrm{mg}$ protein $(n=7, P<0.01$ vs. control). The addition of glucose to hypoxic medium significantly attenuated this decline in ATP: after $2 \mathrm{~h}$ of hypoxia ATP levels fell from $40.5 \pm 3.5$ to $32.2 \pm 3.8 \mathrm{nmol} / \mathrm{mg}$ protein, a statistically insignificant downward trend. However, this level was

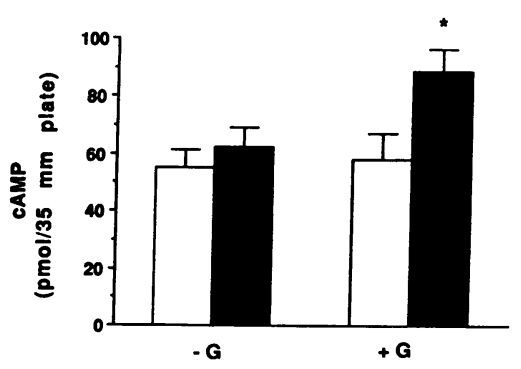

Figure 5. The effect of hypoxia in the presence and absence of glucose on $100 \mu \mathrm{M}$ forskolin-stimulated cAMP generation for 5 min in intact myocytes. (Left) $100 \mu \mathrm{M}$ forskolin-stimulated cAMP generation was unchanged after $120 \mathrm{~min}$

of hypoxia (solid bar) compared with normoxia (open bar) in the absence of $5 \mathrm{mM}$ D-glucose (-G). (Right) $100 \mu \mathrm{M}$ forskolin-stimulated cAMP increased after $120 \mathrm{~min}$ of hypoxia in the presence of 5 $\mathrm{mM}$ D-glucose $(+G)$ (solid bar) compared with normoxic control levels (open bar). ${ }^{*} P<0.025, n=7$.

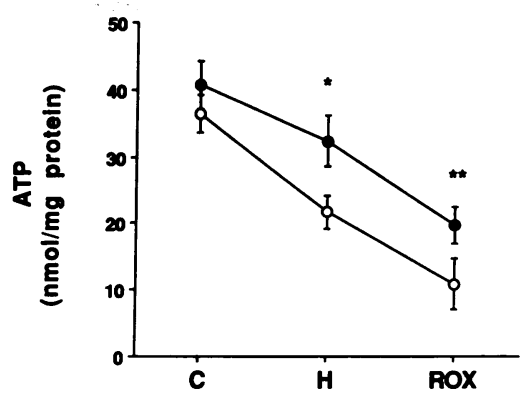

Figure 6. The effect of hypoxia and reoxygenation on intracellular ATP content in the presence (open circles) and absence (closed circles) of $5 \mathrm{mM}$ D-glucose. ATP levels were unaltered by glucose under normoxic conditions (C). During hypoxia $(H)$ and reoxygenation $(R O X)$, the presence of $5 \mathrm{mM}$ D-glucose led to consistently higher ATP levels compared with the absence of glucose $\left({ }^{*} P=0.02\right.$ and ${ }^{* *} P$ $=0.01$ vs. no glucose). Compared with control, ATP levels in the presence of glucose were significantly reduced only with reoxygenation $(P<0.025)$, while in the absence of glucose, levels were significantly reduced compared with control both during hypoxia $(P<0.02)$ and reoxygenation $(P<0.01)$. Data shown are the mean \pm SE for seven separate experiments.

significantly above the value obtained during exposure to glucose-free hypoxic medium $(21.6 \pm 2.5 \mathrm{nmol} / \mathrm{mg}$ protein; $n=7$, $P<0.05$ ). With reoxygenation, ATP fell to $19.6 \pm 2.8 \mathrm{nmol} / \mathrm{mg}$ protein, a level that still significantly exceeded the reoxygenation value in the absence of glucose $(10.8 \pm 3.9 \mathrm{nmol} / \mathrm{mg}$ protein; $P<0.01, n=7$ ). Therefore, the addition of $5 \mathrm{mM}$ D-glucose to hypoxic medium provides substantial protection against the fall in intracellular ATP levels, but does not prevent a significant reduction in ATP observed upon reoxygenation.

Glucose protects against hypoxia-induced lactate dehydrogenase release. To assess the effect of glucose on myocyte viability after $2 \mathrm{~h}$ of hypoxia we also measured LDH release into the medium. For control cells $\mathrm{LDH}$ release was $<100$ $\mathrm{U} /$ liter, irrespective of glucose content. After $2 \mathrm{~h}$ of hypoxia in the absence of glucose, LDH release averaged $549 \pm 55$ U/liter $(n=6 ; P<0.025)$. This represented an $18 \%$ increase in LDH release when expressed as a percentage of maximum LDH achieved by the freeze-thaw method $(2998 \pm 187 \mathrm{U} /$ liter, $n=6)$. By contrast, levels produced by hypoxic cells supplemented with glucose remained $<100 \mathrm{U} /$ liter. When $\mathrm{LDH}$ release was measured at intermediate time points of 30 and $60 \mathrm{~min}$, enzyme release from either glucose-deprived or supplemented hypoxic cells remained $<100 \mathrm{U} /$ liter. Therefore, glucose attenuates $\mathrm{LDH}$ release after prolonged hypoxia.

Glucose protects against hypoxia-induced decline in beating. As shown in Fig. $7 \mathrm{~A}$, hypoxia caused a marked reduction in beating rates, which was significantly greater in glucose-deprived cells. Reoxygenation restored the beating rate to control levels in glucose-supplemented cells. Although the beating rate increased in glucose-deprived cells after $2 \mathrm{~h}$ of reoxygenation, it was still significantly below control levels (Fig. $7 \mathrm{~A}$ ).

In conjunction with the measurement of beating rates, the proportion of beating cells was also assessed. As can be seen in Fig. $7 \mathrm{~B}$, this measure followed a pattern similar to the alterations in absolute beating rate in response to hyoxia and reoxygenation in the presence or absence of glucose.

\section{Discussion}

The $\beta$-adrenergic receptor-adenylate cyclase system is an important interface between external stimuli and cellular responses. Recent investigations have suggested that changes in 
A.

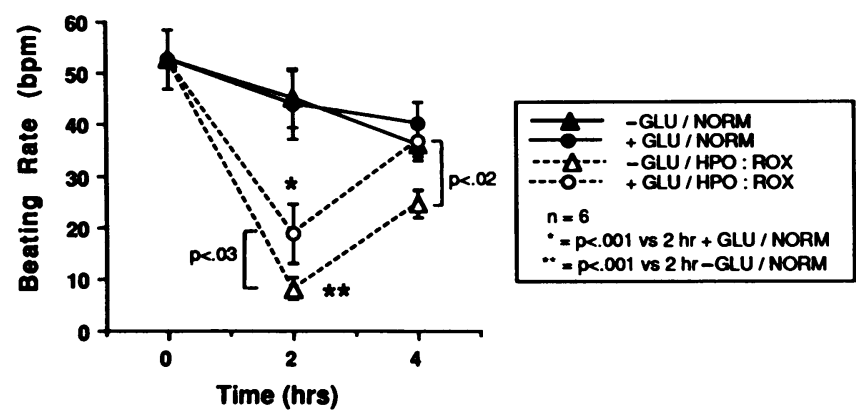

B.

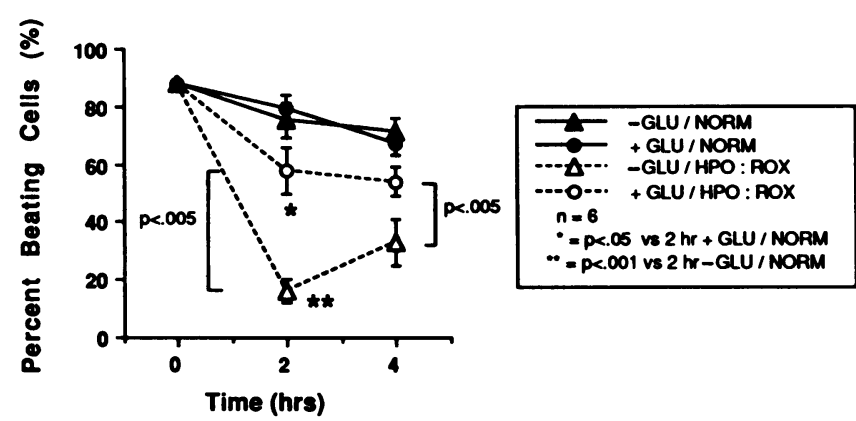

Figure 7. $(A)$ Beating rates per minute (bpm) in the presence $(+)$ or absence (-) of glucose (GLU), normoxia (NORM), hypoxia (HYPO), and reoxygenation $(R O X)$. At time zero, serum-supplemented medium was replaced by MEM with Earle's salts with or without glucose. Beating rates were then counted in each of five microscopic fields from each culture dish. This procedure was repeated after $2 \mathrm{~h}$ of hypoxia or continued normoxia and again after reoxygenation for $2 \mathrm{~h}$. As can be seen, hypoxia resulted in a marked slowing of beating which was reversed by reoxygenation. Compared with glucose deprivation, cells exposed to glucose exhibited a smaller decrease in beating rate and a complete return to control levels. $(B)$ In conjunction with the measurement of beating rates, the proportion of beating cells at each time point was assessed in increments as follows: 0-25, 25-50, 50-75, and $75-100 \%$. Each data point represents the mean of six determinations, each from a separate experiment. As can be seen, the pattern follows the alterations in the absolute beating rate depicted in $A$.

this system may in part mediate the effects of ischemia by influencing contractile activity, arrhythmogensis, and myocardial cell survival $(11,12,19,20,36)$. Although it is well recognized that glucose can attenuate the effects of hypoxia $(9,10)$, previous in vivo studies did not address the separate effects of these two important components of ischemia, hypoxia and glucose deprivation, on the $\beta$-adrenergic receptor-adenylate cyclase system and their impact on myocyte survival. To our knowledge, this is the first report to examine in detail the separate influences of hypoxia and glucose deprivation on alterations in components of the $\beta$-adrenergic receptor-adenylate cyclase system and a marker of cellular injury in intact ventricular myocytes. Our results suggest that hypoxia and glucose deprivation exert discrete effects on the $\beta$-adrenergic receptoradenylate cyclase system by both receptor and postreceptormediated mechanisms. Furthermore, our data indicate that the presence of glucose during the hypoxic insult and reoxygenation attenuates the fall in intracellular adenosine triphosphate concentration and prevents the release of lactate dehydrogenase, a known marker of cellular damage.

Hypoxia downregulates $\beta$-adrenergic receptors to a cytosolic fraction. Previous investigations of myocardial $\beta$-adrenergic receptor density during acute ischemia or hypoxia suggest either an increase $(11,12,16-19)$ or no change $(13,15)$ after varying periods of insult. These studies, in both in vivo and in mammalian cell culture models, used membrane preparations of varying purity, but all routinely disposed of an initial low speed centrifugation pellet, thereby discarding an unknown fraction of the total $\beta$-adrenergic receptor population. In order to avoid this potential methodologic pitfall, we exposed intact neonatal rat myocytes to hypoxic conditions for varying intervals and quantified $\beta$-adrenergic receptors using ${ }^{3} \mathrm{H}$-CGP12177 , a hydrophilic radioligand that binds to cell surface $\beta_{1}$ adrenergic receptors $(23,37)$. Using this method, our data demonstrated a $25-27 \%$ decrease in $\beta$-adrenergic receptor density after 1-2 $\mathrm{h}$ of hypoxia. To corroborate this finding we used a cell lysis/homogenation method in which all fractions were analysed using ${ }^{125}$ I-ICYP. Again, we demonstrated a 20\% decline in $\beta$-receptor density in the membrane fraction. These results, using both ${ }^{3} \mathrm{H}-\mathrm{CGP}-12177$ and ${ }^{125} \mathrm{I}-\mathrm{ICYP}$, are consistent with the recent observations of Marsh and Sweeney in an intact embryonic avian myocyte model (38).

Beta-adrenergic receptors also exist in a cytoplasmic (light vesicle) domain, as defined by their ultracentrifugation sedimentation characteristics $(20,39,40)$. This population may serve as a reserve pool for receptor cycling to and from the cell surface (41). Our data are the first to demonstrate that the hypoxia-induced fall in cell surface receptors is associated with a concomitant rise in a cytoplasmic $\beta$-receptor population. This cytoplasmic preparation was obtained by 24 -h ultracentrifugation of the supernatant from the membrane fraction. Thus, the entire $\beta$-adrenergic receptor population was analyzed and no cellular fraction was discarded. The increase in cytoplasmic receptor density suggests that hypoxia downregulates membrane-associated $\beta$-adrenergic receptors to an intracellular location.

In contrast, Buja et al. (42) and Thandroyen et al. (16), in a similar myocyte culture model exposed to metabolic inhibitors and hypoxia, respectively, reported that $\beta$-adrenergic receptor density in a membrane fraction either fell after irreversible cell damage or increased after $2 \mathrm{~h}$ of hypoxia. Using an identical membrane purification method, we analyzed the supernatant routinely discarded by these investigators and identified a large population of $\beta$-adrenergic receptors that approximated the receptor density in the assayed fraction. This observation emphasizes the potential methodologic pitfalls of analyzing selected cellular fractions that may exclude a large proportion of the $\beta$-adrenergic receptor population. Recently, Heathers et al. observed no significant alteration in $\beta$-adrenergic receptor density after 10-60 min of hypoxia in intact adult canine myocytes (43). While this observation may represent an inherent difference between neonatal rat and adult canine myocyte models, the choice of radioligand may be a key consideration. At these time points (10-60 min), Heathers et al. used ${ }^{3} \mathrm{H}$-dihydroalprenolol (DHA), a probe that measures total cellular (membrane bound and cytosolic) $\beta$-adrenergic receptor binding sites, and thus may have been unable to detect shifts in $\beta$-adrenergic receptors between different cellular compartments.

The decrease in $\beta$-adrenergic receptor density that we observed is consistent with the recent observàtions of Bernstein et 
al. in an in vivo lamb hypoxia model (44) and of Wolff et al. in an in vivo rabbit acute ischemia model (21). In the latter model, a crude membrane preparation that more completely represents the overall $\beta$-adrenergic receptor population was used. These investigators noted a decrease in $\beta$-adrenergic receptor density after $30 \mathrm{~min}$ of coronary occlusion and duplicated previous findings of others if a "purified" membrane preparation was employed.

We observed, as did Marsh and Sweeney (38), that reoxygenation was associated with a return of reduced $\beta$-adrenergic receptor density to control levels. This suggests that myocytes exposed to hypoxia are still viable and that reoxygenation is associated with a return to the cell surface of a previously downregulated $\beta$-receptor population. Although it is an unlikely explanation, we cannot exclude the possibility of new $\beta$-adrenergic receptor synthesis accounting for this return of receptors to the cell surface during reoxygenation.

Glucose independently regulates (-)-norepinephrine-stimulated cAMP accumulation. Several clinical trials have reported an improvement in hemodynamic measurements and reduced mortality in patients receiving intravenous glucose alone or in the form of a glucose infusion containing insulin and potassium during acute myocardial infarction (45-48). It is well established that within minutes after acute coronary occlusion metabolic changes result that, if prolonged, adversely affect myocardial cell survival. Glucose may enhance myocardial cell viability during an ischemic or hypoxic insult and reperfusion/ reoxygenation by supporting glycolytic ATP production, forestalling glycogen depletion, reducing free fatty acid production, increasing the rate of adenine nucleotide pool regeneration, and attenuating the shortening of action potential duration (6, $7,49-54)$. In a recent report, Runnman et al. noted that enhanced use of exogenous glucose improved cardiac function in an isolated rabbit interventricular septal preparation without increasing total glycolytic flux or tissue high energy phosphate levels (55).

However, these previous reports did not consider the potential favorable impact of glucose on the maintenance of adenylate cyclase activity and the resultant agonist-stimulated cAMP production during hypoxia. We observed a significant decline in NE-stimulated cAMP generation after $2 \mathrm{~h}$ of glucose-free hypoxia which was unchanged after $2 \mathrm{~h}$ of reoxygenation (Fig. 3 ). This finding is consistent with the observations of Heathers and co-workers who noted a decrease in (-)-isoproterenol-stimulated cAMP content after 60-120 min of hypoxia at a low glucose concentration ( $1 \mathrm{mM})$ in intact adult canine myocytes (43). Our data show that the addition of $5 \mathrm{mM}$ D-glucose not only dramatically reversed this decline but enhanced cAMP accumulation after the hypoxic insult. After $2 \mathrm{~h}$ of hypoxia and reoxygenation in the presence of glucose, NE-stimulated cAMP levels were still elevated. Furthermore, the addition of glucose at the onset of reoxygenation after a glucose-free hypoxic interval returned agonist-stimulated cAMP generation toward control levels (Fig. 3). It should be noted that in the absence of glucose, shorter periods of hypoxia, e.g., $30 \mathrm{~min}$, had no effect on NE-stimulated cAMP accumulation $(37 \pm 5$ vs. $38 \pm 4 \mathrm{pmol} \mathrm{cAMP} / 35 \mathrm{~mm}$ plate; $n=7, P=\mathrm{NS}$ ). The subsequent reduction in cAMP generation suggests that glucose delays or prevents the development of the abnormalities in signal transduction that we observed.

These observations are consistent with those of Marsh and Sweeney in an embryonic chick myocyte model (38). They also noted a fall in agonist [(-)-isoproterenol]-stimulated cAMP generation during hypoxia in the absence of glucose. However, the decline in agonist-stimulated cAMP generation persisted after glucose supplementation and, in contrast to our results, no increase in cAMP generation was observed. Moreover, no experiments investigating the effects of glucose supplementation during hypoxia on ATP levels were reported. Alternatively, this disparate response could reflect an inherent difference between mammalian and avian species, or the more severe hypoxia reported by Marsh and Sweeney (38). The $\mathrm{pO}_{2}$ levels achieved in our experiments are consistent with those reported by others (56), but greater than those observed by mass spectrometry in working myocardium (57). Nevertheless, the reversible alterations in $\beta_{1}$-adrenoceptors, signal transduction and beating, and the decline in ATP levels all point to a functionally significant degree of hypoxia. As noted by O'Riordan et al. (57), in working myocardium, where $\mathrm{O}_{2}$ extraction is already very high and tissue $\mathrm{pO}_{2}$ low (10-24 Torr), coronary blood flow is limiting, whereas in cell culture, initial $\mathrm{pO}_{2}$ is high ( $\sim 166$ Torr). Thus, in our system it is possible that the marked $86 \%$ reduction in $\mathrm{pO}_{2}$ is the key event that triggers the biochemical abnormalities we observed and is consistent with the possibility that molecular oxygen, per se, plays a separate key role in maintaining cell function and viability.

Our observation of an increase in NE-stimulated cAMP generation after glucose supplementation during hypoxia is of particular interest given the hypoxia-induced decline in $\beta$ adrenergic receptor density both in the presence and absence of glucose. These considerations suggest that the decline in agonist-stimulated cAMP accumulation during hypoxia in the absence of glucose cannot be explained exclusively on the basis of reduced $\beta$-adrenergic receptor density or by reduced ATP levels. Furthermore, the increase in cAMP generation does not result from enhanced agonist-receptor coupling, as there was no difference in (-)-isoproterenol displacement curves after 2 $h$ of hypoxia in the presence or absence of glucose (Fig. 4), an observation also made by Marsh and Sweeney (38).

Glucose affects postreceptor-mediated cAMP generation. An additional mechanism for the regulation of cAMP is suggested by our observation that forskolin-stimulated cAMP accumulation remained at levels similar to those of normoxic cells during hypoxia in the absence of glucose and increased during hypoxia in the presence of glucose. These data are in contrast to those of Thandroyen et al. who reported a decrease in forskolin-stimulated adenylate cyclase activity after 120$150 \mathrm{~min}$ of hypoxia (16). However, the glucose content in the hypoxic medium at this time point was not defined. In adult canine myocytes, Heathers and co-workers (43) noted a $40 \%$ decrease from control values in forskolin-stimulated cAMP generation after $2 \mathrm{~h}$ of hypoxia in the presence of $1 \mathrm{mM}$ glucose. However, in their model hypoxia of this duration was associated with severe cellular damage as assessed by morphologic indices and lactate dehydrogenase and creatine kinase release. Therefore, in their preparation, it is uncertain if the decrease in forskolin-stimulated cAMP generation reflects specific changes in the adenylate cyclase pathway or is simply a harbinger of cell death.

As noted above, $2 \mathrm{~h}$ of hypoxia in the absence of glucose attenuated $1 \mu \mathrm{M}$ NE-stimulated cAMP generation compared with normoxia. In contrast, cAMP accumulation in response to forskolin was not affected and was actually increased by $60 \%$ above levels stimulated by $1 \mu \mathrm{M}$ NE. Thus, even in the absence 
of glucose, there was sufficient ATP to act as substrate for adenylate cyclase to catalyze nonadrenergic receptor-mediated cAMP generation. While alterations in $\beta$-adrenergic receptor density and ATP concentration may influence cAMP generation, postreceptor mechanisms may be of equal or even greater importance. Since forskolin bypasses the $\beta$-adrenergic receptor and, in conjunction with $G_{s}$, acts directly on the catalytic unit of adenylate cyclase, one interpretation of our data is that hypoxia, especially in the presence of glucose, may enhance G-protein-catalytic unit coupling, permitting more efficient signal transduction. Although the mechanism of this augmentation is not readily apparent from our data it may, in part, be due to the beneficial effect of glucose supplementation on protein kinasedependent substrate phosphorylation or on membrane stability (see below).

Glucose attenuates the fall in adenosine triphosphate levels. Compared with ATP produced in mitochondria, which use oxidative phosphorylation, ATP generated by glycolysis may preferentially support specific sarcolemmal-associated functions and maintain cellular integrity $(7,50,52,53,58)$. Moreover, compared with inhibition of oxidative metabolism, inhibition of glycolytic pathways during low flow ischemia results in accelerated enzyme release and a more rapid onset of myocardial contracture $(7,50,52)$. Reports in cultured avian myocytes have extended these observations to suggest that rates of glycolysis are closely linked to maintenance of normal membrane depolarization and contraction during inhibition of oxidative phosphorylation $(50,59)$. Compartmentalization of ATP generated from exogenous glucose versus endogenous glycogen has been demonstrated in vascular smooth muscle (60) and postulated to occur in vivo in ischemic myocardium (61). In perfused hypoxic rat hearts and rabbit interventricular septum $(7,54)$ and in isolated adult rat myocytes $(62)$, glucose plays a special role in the preservation of cell viability, morphology, ATP concentration, and in forestalling intracellular enzyme release. This beneficial effect extends to the preservation of intracellular pH and myocardial tension development (54).

It has been proposed that key glycolytic enzymes present in the cell membrane or attached to the cytoskeleton use exogenous glucose to produce glycolytic ATP (63), and this "compartmentalized" ATP may preferentially maintain cell membrane integrity and function and thus ultimately improve cell survival. Our observation that $5 \mathrm{mM}$ D-glucose significantly attenuated the hypoxia-induced fall in ATP at 1 and $2 \mathrm{~h}$ of hypoxia and after reoxygenation is consistent with an increase ATP generated by glycolysis during hypoxia $(62,63)$ and may directly relate to our observation that glucose supplementation during hypoxia-prevented LDH release. This may in part also explain the fall in NE-stimulated cAMP accumulation after hypoxia in the absence of glucose as compared with the increase in cAMP stimulated by NE in the presence of glucose.

Further investigations are required to define the possible contribution of ATP compartmentalization to the maintenance or enhancement of membrane-bound enzyme activity. However, the fall in NE-stimulated cAMP content does not appear to be due to reduced ATP levels alone, because forskolin-stimulated (postreceptor-mediated) cAMP exceeded NEstimulated (receptor-mediated) cAMP generation under similar hypoxic conditions, regardless of glucose content. In this connection, Heathers et al. (43) recently proposed that hypoxia in the absence of glucose uncouples the $\beta$-adrenergic receptor from the adenylate cyclase complex thereby altering receptor- mediated signal transduction. Our observation that hypoxia, irrespective of glucose content, does not influence $\beta$-adrenergic receptor affinity for (-)-isoproterenol leads us to suggest that the G-protein-catalytic unit interaction may be the site of uncoupling.

The objective of this study was to determine the independent effects of two components of ischemia, hypoxia and glucose deprivation, on elements of the $\beta$-adrenergic receptoradenylate cyclase system in isolated cultured cardiac myocytes. Extrapolation of our results to in vivo models of ischemia should be done with caution. Clearly, the accumulation of metabolic products of ischemia and the effects of altered $\mathrm{pH}$ and external workload on the intact heart undoubtedly influence the effects of ischemia on the individual myocyte. However, exclusion of these confounding factors is important to further investigations of the precise determinants and relative contributions of hypoxia and glucose deprivation to cell injury and survival.

\section{Acknowledgments}

The authors thank Dr. Keith Lurie for his advice in these studies.

Supported by grants from the National Heart, Lung and Blood Institute Program Project grant HL-25847, the Department of Veterans Affairs Research Service, and the California Affiliate of the American Heart Association. Dr. Rocha-Singh was the recipient of an Individual National Research Service award (HL-07507-02).

\section{References}

1. Braunwald, E., and R. A. Kloner. 1982. The stunned myocardium: prolonged, post-ischemic ventricular dysfunction. Circulation. 56:1146-1149.

2. Jennings, R. B., and C. Steenbergen. 1985. Nucleotide metabolism and cellular damage in myocardial ischemia. Annu. Rev. Physiol. 47:727-749.

3. Hearse, D. J., and E. B. Chain. 1972. The role of glucose in the survival and recovery of the anoxic isolated perfused rat heart. Biochem. J. 128:1125-1133.

4. Langer, G. A., J. N. Weiss, and H. R. Schelbert. 1987. Cardiac ischemia. Part 1-Metabolic and physiological responses. West. J. Med. 146:713-723.

5. Cobbe, S. M., and P. A. Poole-Wilson. 1980. The time of onset and severity of acidosis in myocardial ischemia. J. Mol. Cell. Cardiol. 12:745-760.

6. Morena, H., M. J. Janse, W. T. Fiolet, W. J. G. Krieger, H. Crijns, and D. Durrer. 1980. Comparison of the effects of regional ischemia, hypoxia, hyperkalemia, and acidosis on intracellular and extracellular potentials and metabolism in the isolated porcine heart. Circ. Res. 46:634-646.

7. Bricknell, O. L., and L. H. Opie. 1978. Effects of substrates on tissue metabolic changes in the isolated rat heart during underperfusion and on release of lactate dehydrogenase and arrhythmias during reperfusion. Circ. Res. 43:102115.

8. Sodi-Pallares, D., M. R. Testelli, and B. L. Fishleder. 1962. Effects of an intravenous infusion of a glucose-potassium-insulin solution on the electrocardiographic signs of myocardial infarction. Am. J. Cardiol. 9:166-181.

9. Kobayashi, A., J. Kaiya, T. Yamashita, K. Ishizaka, H. Hayashi, T. Kamikawa, and N. Yamazaki. 1984. Effects of glucose-insulin-potassium solution on free-fatty acid metabolism in ischemic myocardium. Jpn. Circ. J. 48:591-595.

10. Hoekenga, D. E., J. R. Brainard, and J. Y. Hutson. 1988. Rates of glycolysis and glycogenolysis during ischemia in glucose-insulin-potassium-treated perfused hearts: a ${ }^{13} \mathrm{C},{ }^{31} \mathrm{P}$ nuclear magnetic resonance study. Circ. Res. 62:10651074.

11. Mukherjee, T., T. M. Wong, L. M. Buja, R. J. Lefkowitz, and J. T. Willerson. 1979. Beta-adrenergic and muscarinic cholinergic receptors in canine myocardium: effects of ischemia. J. Clin. Invest. 64:1423-1428.

12. Maisel, A. S., H. J. Motulsky, M. G. Ziegler, and P. A. Insel. 1987. Ischemia- and agonist-induced changes in $\alpha$ - and $\beta$-adrenergic receptor traffic in guinea pig heart. Am. J. Physiol. 253:H11159-1166.

13. Karliner, J. S., M. Stevens, W. Woloszyn, N. Honbo, G. Blaug, and J. I. E. Hoffman. 1989. Effects of acute ischemia in the dog on myocardial blood flow, beta receptors and adenylate cyclase activity with and without chronic beta blockade. J. Clin. Invest. 83:474-481.

14. Vatner, D. E., D. R. Knight, Y. T. Shen, J. X. Thomas, C. J. Homcy, and S. F. Vatner. 1988. One hour of myocardial ischemia in conscious dogs increases $\beta$-adrenergic receptors, but decreases adenylate cyclase activity. J. Mol. Cell. Cardiol. 20:75-82. 
15. Freissmuth, M., W. Schutz, M. Weindlmayer-Gottel, M. Zimpfer, and C. K. Spiss. 1987. Effects of ischemia on the canine myoycardial $\beta$-adrenoceptorlinked adenylate cyclase system. J. Cardiovasc. Pharmacol. 10:568-574.

16. Thandroyen, F. T., K. Muntz, T. Rosenbaum, B. Ziman, J. T. Willerson, and L. M. Buja. 1989. $\beta$-receptor-adenylate cyclase coupling in hypoxic neonata rat ventricular myocytes. Am. J. Physiol. 256:H1209-H1217.

17. Devos, C., P. Robberecht, P. Norkin, M. Waelbroeck, M. Clinet, J. C. Camus, P. Beaufort, P. Schoenfeld, and J. Christophe. 1985. Uncoupling between beta-adrenoceptors and adenylate cyclase in dog ischemic myocardium. NaunynSchmiedeberg's Arch. Pharmacol. 331:71-75.

18. Matsuo, R., J. Hayashi, H. Manabe, and Y. Watanabe. 1986. Effects of hypoxia on beta and alpha receptor density in isolated mammalian cardiac myocytes. J. Am. Coll. Cardiol. 7:81a. (Abstr.)

19. Mukherjee, A., L. R. Bush, K. E. McCoy, R. J. Duke, H. Hagler, L. M Buja, and J. T. Willerson. 1982. Relationship between $\beta$-adrenergic receptor numbers and physiological responses during experimental canine myocardial ischemia. Circ. Res. 50:735-741.

20. Maisel, A. S., H. J. Motulsky, and P. A. Insel. 1985. Externalization of $\beta$-adrenergic receptors promoted by myocardial ischemia. Science (Wash. DC). 230:183-186

21. Wolff, A. A., D. K. Hines, and J. S. Karliner. 1989. Refined membrane preparations mask the ischemic fall in myocardial $\beta$-receptor density. Am. J. Physiol. 257:H1032-H1036.

22. Simpson, P. C., and S. Savion. 1982. Differentiation of rat myocytes in single cell culture with and without proliferating nonmyocardial cells: cross striation, ultrastructure and chronotropic responses to catecholamines. Circ. Res. 51:787-801.

23. Staehelin, M., P. Simons, K. Jaeggi, and N. Wigger. 1983. CGP-12177. A hydrophilic $\beta$-adrenergic receptor radioligand reveals high affinity binding of agonists to intact cells. J. Biol. Chem. 258:3496-3502.

24. Scatchard, G. 1949. The attraction of proteins for small molecules and ions. Ann. NY Acad. Sci. 51:660-672.

25. Karliner, J. S., P. C. Simpson, N. Honbo, and W. Woloszyn. 1986. Mechanisms and time course of $\beta_{1}$-adrenoceptor desensitisation in mammalian cardiac myocytes. Cardiovasc. Res. 20:221-228.

26. Hoyer, D., G. Engel, and R. Berthold. 1982. Binding characteristics of $(+),( \pm)-$, and $(-)-{ }^{125}$ Iodo)cyanopindolol to guinea-pig left ventricle membranes. Naunyn-Schmiedeberg's Arch. Pharmacol. 318:319-329.

27. Lowry, O. H., N. J. Rosenbrough, A. L. Farr, and R. J. Randall. 1951. Protein measurement with the Folin phenol reagent. J. Biol. Chem. 265:265-75.

28. Karliner, J. S., P. C. Simpson, J. E. Taylor, N. Honbo, and W. Woloszyn.

1985. Adrenergic receptor characteristics of cardiac myocytes cultured in serum-

free medium: comparison with serum-supplemented medium. Biochem. Biophys. Res. Commun. 128:376-382.

29. Reithmann, C., and K. Werdan. 1989. Noradrenaline-induced desensitization in cultured heart cells as a model for the defects of the adenylate cyclase system in severe heart failure. Naunyn-Schmiedeberg's Arch. Pharmacol. 339:138-144.

30. Lau, Y. H. R. B. Robinson, M. R. Rosen, and J. P. Bilezikian 1980. Subclassification of $\beta$-adrenergic receptors in cultured rat cardiac myoblasts and fibroblasts. Circ. Res. 47:41-48.

31. Steiner, A. L., C. W. Parker, and D. M. Kipnis. 1972. Radioimmunoassay for cyclic nucleotides. J. Biol. Chem. 247:1106-1113.

32. Lowry, O. H., and J. V. Passeneau. 1972. Flexible Systems of Enzymatic Analysis. Academic Press, New York. 151-156.

33. Kidwai, A. M., M. A. Radcliffe, G. Duchon, and E. E. Daniel. 1971. Isolation of plasma membrane from cardiac muscle. Biochem. Biophys. Res. Commun. 45:901-910.

34. Seamon, K., and J. W. Daly. 1981. Activation of adenylate cyclase by the diterpene forskolin does not require the nucleotide regulatory protein. J. Biol. Chem. 256:9799-9801.

35. Darfler, F. J., L. C. Mahan, A. M. Koachman, and P. A. Insel. 1982 Stimulation by forskolin of intact $\$ 49$ lymphoma cells involves the nucleotide regulatory protein of adenylate cyclase. J. Biol. Chem. 257:11901-11907.

36. Corr, P. B., J. A. Shayman, J. B. Kamer, and R. J. Kipnis. 1981. Increased $\alpha$-adrenergic receptors in ischemic cat myocardium. A potential mediator of electrophysiological derangements. J. Clin. Invest. 67:1232-1236.

37. Hertel, C., P. Muller, M. Portenier, and M. Staehelin. 1983. Determination of the desensitization of $\beta$-adrenergic receptors by $\left[{ }^{3} \mathrm{H}\right]-\mathrm{CGP}-12177$. Biochem. J. 216:669-674.

38. Marsh, J. D., and K. A. Sweeney. 1989. $\beta$-adrenergic receptor regulation during hypoxia in intact cultured heart cells. Am. J. Physiol. 256:H275-H281.

39. Waldo, G. L., J. K. Northup, J. P. Perkins, and T. K. Harden. 1983 Characterization of an altered membrane form of the beta-adrenergic receptor produced during agonist-induced desensitization. J. Biol. Chem. 258:1390013908.
40. Mahan, L. C., H. J. Motulsky, and P. A. Insel. 1985. Do agonists promote rapid internalization of beta-adrenergic receptors? Proc. Natl. Acad. Sci. USA. 82:6566-6570

41. Maisel, A. S., H. J. Motulsky, and P. A. Insel. 1987. Life cycles of cardiac $\alpha_{1}$ - and $\beta$-adrenergic receptors. Biochem. Pharmacol. 36:1-6.

42. Buja, L. M., K. H. Muntz, T. Rosenbaum, Z. Haghani, D. K. Buja, A. Sen, K. R. Chien, and J. T. Willerson. 1985. Characterization of a potentially reversible increase in $\beta$-adrenergic receptors in isolated, neonatal rat cardiac myocytes with impaired energy metabolism. Circ. Res. 57:640-645.

43. Heathers, G. P., P. C. Lee, K. A. Yamada, P. B. Corr. 1990. The influence of hypoxia on beta-adrenergic receptors and their intracellular coupling in isolated adult canine myocytes. Coronary Artery Dis. 1:97-110.

44. Bernstein, D., E. Voss, and S. Huang. 1989. Differential regulation of right and left ventricular $\beta$-adrenergic receptors during chronic hypoxia. J. Cell. Biochem. 13E(Suppl):205

45. Martinez, E. E., J. S. Telles, T. L. R. Martinez, O. P. Portugal, R. F Guimates, J. L. V. Herrmann, E. N. Lamounier, A. A. DePaola, C. R. C. Auriemo, and J. A. Ambrose. 1987. The effect of glucose on myocardial substrate utilization in acute myocardial infarction or angina pectoris. Am. J. Cardiol 60:947-951.

46. Rogers, W. J., P. H. Segal, H. G. McDaniels, J. A. Mantle, R. O. Russell, and C. E. Rackely. 1979. Prospective randomized trial of glucose-insulin-potassium in acute myocardial infarction. Am. J. Cardiol. 43:801-809.

47. Mantle, J. A., W. J. Rogers, L. R. Smith, H. G. McDaniel, S. E. Papapietro, and R. O. Russell. 1981. Clinical effects of glucose-insulin-potassium on left ventricular function in acute myocardial infarction: results from a randomized clinical trial. Am. Heart J. 1022:313-324.

48. Rogers, W. J., A. W. Stanley, J. B. Breimig, J. W. Prather, H. G. McDaniel, R. E. Moraski, J. A. Mantle, R. O. Russell, and C. E. Rackely. 1976. Reduc tion of hospital mortality rate of acute myocardial infarction with glucose-insulin-potassium infusion. Am. Heart J. 92:441-454.

49. Nakamura, S., T. Kiyosue, and M. Arita. 1989. Glucose reverses 2,4-dinitrophenol induced changes in action potentials and membrane currents of ginea pig ventricular cells via enhanced glycolysis. Cardiovasc. Res. 23:286-294.

50. Doorey, A. J., and W. H. Barry. 1983. The effects of inhibition of oxidative phosphorylation and glycolysis on contractility and high-energy phosphate content in cultured chick heart cells. Circ. Res. 53:192-201.

51. Bricknell, O. L., P. S. Daries, and L. H. Opie. 1981. A relationship between adenosine triphosphate, glycolysis and ischemic contracture in the isolated rat heart. J. Mol. Cell. Cardiol. 13:941-945.

52. Sako, E. Y., P. B. Kingsley-Hickman, A. H. L. From, J. E. Foker, and K Ugurbil. 1988. ATP synthesis kinetics and mitochondrial function in the postischemic myocardium as studied by ${ }^{31}$ P NMR. J. Biol. Chem. 263:10600-10607.

53. Lipasti, J. A., T. J. Nevalainen, K. A. Alanen, and M. A. Tolvanen. 1984. Anaerobic glycolysis and the development of ischemic contracture in isolated rat heart. Cardiovasc Res 18:145-148.

54. Weiss, J., and B. Hiltbrand. 1985. Functional compartmentation of glycolytic versus oxidative metabolism in isolated rabbit heart. J. Clin. Invest. 75:436447.

55. Runnman, E. M., S. T. Lamp, and J. N. Weiss. 1990. Enhanced utilization of exogenous glucose improves cardiac function in hypoxic rabbit ventricle without increasing total glycolytic flux. J. Clin. Invest. 86:1222-1233.

56. Freyss-Beguin, M., E. Millanvoye-Van Brussel, and D. Duval. 1989. Effect of oxygen deprivation on metabolism of arachidonic acid by cultures of rat heart cells. Am. J. Physiol. 257:H444-H451.

57. O'Riordan, J. B., J. T. Flaherty, S. F. Khuri, R. K. Brawley, B. Pitt, and V. L. Gott. 1977. Effects of atrial pacing on regional myocardial gas tensions with critical coronary stenosis. Am. J. Physiol. 232:H49-H53.

58. Weissler, A. M., F. A. Kruger, A. Baba, D. G. Scarpelli, R. F. Leighton, and J. K. Gallimore. 1968. Role of anaerobic metabolism in the preservation of functional capacity and structure of anoxic myocardium. J. Clin. Invest. 47:403416

59. Hasin, Y., and W. Barry. 1984. Myocardial metabolic inhibition and membrane potential, contraction, and potassium uptake. Am. J. Physiol. 247:H322-H329.

60. Lynch, R. M., P. A. Poole-Wilson, and A. Williams. 1983. Compartmentation of glycolytic and glycogenolytic metabolism in vascular smooth muscle. Science (Wash. DC). 222:1344-1346.

61. Dennis, S. C., D. J. Hearse, and D. J. Coltart. 1982. Metabolic effects of substrate on the isolated guinea-pig heart in relationship to arrhythmias during reperfusion. Cardiovasc. Res 16:209-219.

62. Hohl, C., A. Ansel, R. Altschuld, and G. Brierley. 1982. Contracture of isolated rat heart cells on anaerobic to aerobic transition. Am. J. Physiol. 242: $\mathrm{H} 1022-\mathrm{H} 1030$

63. Weiss, J. N., and S. T. Lamp. 1987. Glycolysis preferentially inhibits ATP-sensitive $\mathrm{K}^{+}$channels in isolated guinea pig cardiac myocytes. Science (Wash. DC). 238:67-69. 